\title{
INTERACTIONS BETWEEN GREEN MANURE AND ROCK PHOSPHATE ON SOIL NUTRIENT CYCLING ON FAMILY FARMS ${ }^{1}$
}

\author{
MARCELO HENRIQUE SIQUEIRA LEITE ${ }^{2 *}$, EDUARDO GUIMARÃES COUTO ${ }^{3}$, JENNIFER MARIE BLESH ${ }^{4}$
}

\begin{abstract}
Family farming is important for the production of food for human consumption, but it lacks resources to invest in the soil fertility of its crops. The objective of this study was to analyze whether the use of green manures increases soil fertility in terms of the nutrients $\mathrm{N}, \mathrm{P}$ and $\mathrm{K}$ with low environmental risk for family agricultural production. An experiment was set up in the State of Mato Grosso (Brazil), in randomized complete block design, with a $6 \times 3$ factorial scheme, four replications, corresponding to 6 types of plants and 3 doses of phosphorus. Leguminous green manure plants were: velvet bean, Crotalaria juncea, Crotalaria ochroleuca and dwarf pigeon pea, in addition to plots with pearl millet and weedy fallow control. Rock phosphate (i.e., reactive natural phosphate) was applied as a source of phosphorus at 0, 50 and $100 \mathrm{~kg} \mathrm{P}_{2} \mathrm{O}_{5} \mathrm{ha}^{-1}$. The species used as green manure were cut in full bloom and the levels of N, P, K and C in plants and soil were determined. Leguminous green manure plants, after mineralization, increased the stocks of $\mathrm{N}, \mathrm{P}$ and $\mathrm{K}$ in the soil. Crotalaria juncea was the one that reached the highest $\mathrm{N}$ accumulation in its constitution, being recommended in the intercropping with species with $\mathrm{C} / \mathrm{N}$ ratio $>30$ to minimize risks of contamination with nitrate in the soil. This work concluded that the managements with green manure plants, especially Crotalaria ochroleuca, are recommended and environmentally safe technical alternatives for family farming.
\end{abstract}

Keywords: Mineralization. Soil fertility. Legumes.

\section{INTERAÇÕES ENTRE ADUBOS VERDES E FOSFATO NATURAL NA CICLAGEM DE NUTRIENTES DO SOLO PARA AGRICULTURA FAMILIAR}

\begin{abstract}
RESUMO - A agricultura familiar é importante para a produção de alimentos destinados ao consumo humano, porém é carente de recursos para investir na fertilidade do solo de suas lavouras. O objetivo deste estudo foi analisar se o uso de adubos verdes aumenta a fertilidade do solo quanto os nutrientes $\mathrm{N}, \mathrm{P}$ e K com baixo risco ambiental para a produção agrícola familiar. Foi implantado um experimento no Estado de Mato Grosso (Brasil), em Delineamento em Blocos Casualizados, Fatorial 6 x 3, com 4 repetições, sendo 6 tipos de plantas e 3 doses de fósforo. As plantas de adubação verde leguminosas foram: mucuna-cinza, Crotalaria juncea, Crotalaria ochroleuca e guandu-anão, também se utilizou parcelas com milheto e vegetações espontâneas. Foi aplicado o fosfato natural reativo nas doses de 0,50 e $100 \mathrm{~kg} \mathrm{P}_{2} \mathrm{O}_{5} \mathrm{ha}^{-1}$. As espécies utilizadas como adubos verdes foram cortadas no pleno florescimento e determinados os teores de N, P, K e C nas plantas e no solo. As plantas de adubação verde leguminosas, após mineralização, elevaram os estoques de $\mathrm{N}, \mathrm{P}$ e $\mathrm{K}$ do solo. Crotalaria juncea foi à que alcançou o maior acúmulo de $\mathrm{N}$ em sua constituição Este trabalho concluiu que os manejos com plantas de adubação verde, com destaque para Crotalaria ochroleuca, são alternativas técnicas recomendáveis para a agricultura familiar.
\end{abstract}

Palavras-chave: Mineralização. Fertilidade do solo. Leguminosas.

\footnotetext{
${ }^{*}$ Corresponding author

${ }^{1}$ Received for publication in $06 / 10 / 2020$; accepted in $08 / 25 / 2021$.

Paper extracted from the doctoral thesis of the first author.

${ }^{2}$ Instituto Nacional de Colonização e Reforma Agrária, Cáceres, MT, Brazil; sleitebrum@gmail.com - ORCID: 0000-0001-5084-8868.

${ }^{3}$ Graduate Program in Tropical Agriculture, Faculty of Agronomy and Zootechnics, Universidade Federal de Mato Grosso, Cuiabá, MT, Brazil; egcouto@gmail.com - ORCID: 0000-0002-5271-9709.

${ }^{4}$ University of Michigan, An Arbor, USA, jblesh@umich.edu - ORCID: 0000-0003-3807-2352.
} 


\section{INTRODUCTION}

In recent decades, the intensification of agriculture has achieved its goal of increasing yield in the field, but with the use of large amounts of fertilizers (SILVA et al., 2014). Between 2011 and 2013, the Brazilian demand for fertilizers increased on average $4.4 \%$ per year (ANDA, 2014), with potassium fertilizer being the largest import, around 95\% (TAVARES; HABERLI JUNIOR, 2011). Despite being a major fertilizer consumer, Brazil has seen a considerable reduction in domestic production and the consequent increase in fertilizer imports in the last 10 years (OLIVEIRA; MALAGOLLI; CELLA, 2019). This shows that Brazil relies heavily on fertilizer imports to meet its needs. Almost 70\% of the fertilizers used in the country come from imports (ANDA, 2019).

Introducing plant diversity in agroecosystems and managing their interactions at low cost is an alternative to generate sustainable production systems, minimizing the use of non-renewable inputs. Increased plant diversity in agricultural systems promotes the provision of ecosystem services that ensure food, energy, water quality and nutrient cycling (FINNEY; WHITE; KAYE, 2016).

Family farming is an important segment for the basic production of food intended for human consumption. Family farmers accounted for $87 \%$ of national cassava production, $70 \%$ of bean production, $34 \%$ of rice production and $46 \%$ of corn production (IBGE, 2017). Despite the importance of family farming for food production, it is not yet the holder of the largest sources of financing or benefits from its production and participation in the Brazilian economy.

Green manure is an alternative for sustainable management with the improvement and maintenance of soil quality and increased levels of organic matter and nutrients, especially in the case of legume species, which perform biological nitrogen fixation (BNF), being a source of organic N (HERNANI; PADOVAN, 2014). Legumes can also be considered a carbon source for agroecosystems, which increases the ecological processes of decomposition and mineralization; consequently, it can provide nutrients for plants destined for production, reducing the use of synthetic fertilizers.

According to Maluf et al. (2015), although research with nutrient cycling in agroecosystems is in full progress, involving several types of plant residues under different edaphoclimatic conditions, little is known about the flow and dynamics in the soil, and there are few studies with mineralization of nutrients from crop residues are scarce aiming to verify the availability to successor plants.

The hypothesis of the present study is that soil management with the interaction between green manures and natural phosphate, besides being a viable alternative as a source of nutrients for family agricultural systems, will promote through ecological processes greater ecosystem services and increased soil fertility. The objectives of this study were to recommend green manure species in interactions with doses of reactive natural phosphate that increase soil N, P and K contents.

\section{MATERIAL AND METHODS}

The study was carried out in the municipality of Araputanga/Mato Grosso/Brazil, in the Florestan Fernandes Settlement Project, with central coordinates: UTM: $\mathrm{N}=8.282 .294 \mathrm{~m}$ and $\mathrm{E}=355.051$ m (Zone 21S, MC 57Wgr, Datum Sirgas 2000) (Figure 1). According to Santos (2000), the region has altitudes ranging from 200 to $300 \mathrm{~m}$ and has annual rainfall totals of 1400 to $1600 \mathrm{~mm}$, from November to April, characterized as rainy season. The dry season occurs during the months from May to October, marked by a drastic reduction in the occurrence of rains. The average annual temperature is greater than $24.9^{\circ} \mathrm{C}$, while the maximums always vary between 32.3 and $32.7^{\circ} \mathrm{C}$.

The experimental area has been fallow in the last five years and had been previously used by family farmers for the production of vegetables. At the beginning of the work, the area was managed with one pass of heavy harrow and two passes of leveling harrow, for cleaning and making it flat to set up the experiment. The first experimental period (year 1) was from November 2014 to July 2015, and the second (year 2) was from November 2015 to July 2016.

The chemical and physical characteristics of the soil at the time of the experiment installation, in the 0-0.2 and 0.2-0.4 m layers, are presented in Table 1. According to Embrapa (2018), the soil was classified as Argissolo Vermelho-Amarelo Eutrófico abrúptico (Ultisol) with sandy/medium texture and moderate A horizon.

The experiment was set up in randomized block design (RBD), in a $6 \times 3$ factorial scheme, with 4 replications. The plots measured $3 \times 3 \mathrm{~m}$, with spacing between plots of $1 \mathrm{~m}$ and usable area of $4 \mathrm{~m}^{2}$ (central), according to Teodoro et al. (2011).

The green manure factor was composed of four legumes (Fabaceae), one grass (Poaceae) and a treatment with spontaneous vegetation. The other factor was composed of three doses of phosphorus: 0,50 and $100 \mathrm{~kg} \mathrm{P}_{2} \mathrm{O}_{5} \mathrm{ha}^{-1}$, using as source the reactive natural phosphate, with available $\mathrm{P}$ content of $15.5 \%$ of $\mathrm{P}_{2} \mathrm{O}_{5}$ (Citric Acid 2\%), of sedimentary and organic origin, from the region of Morocco (Table 2). 

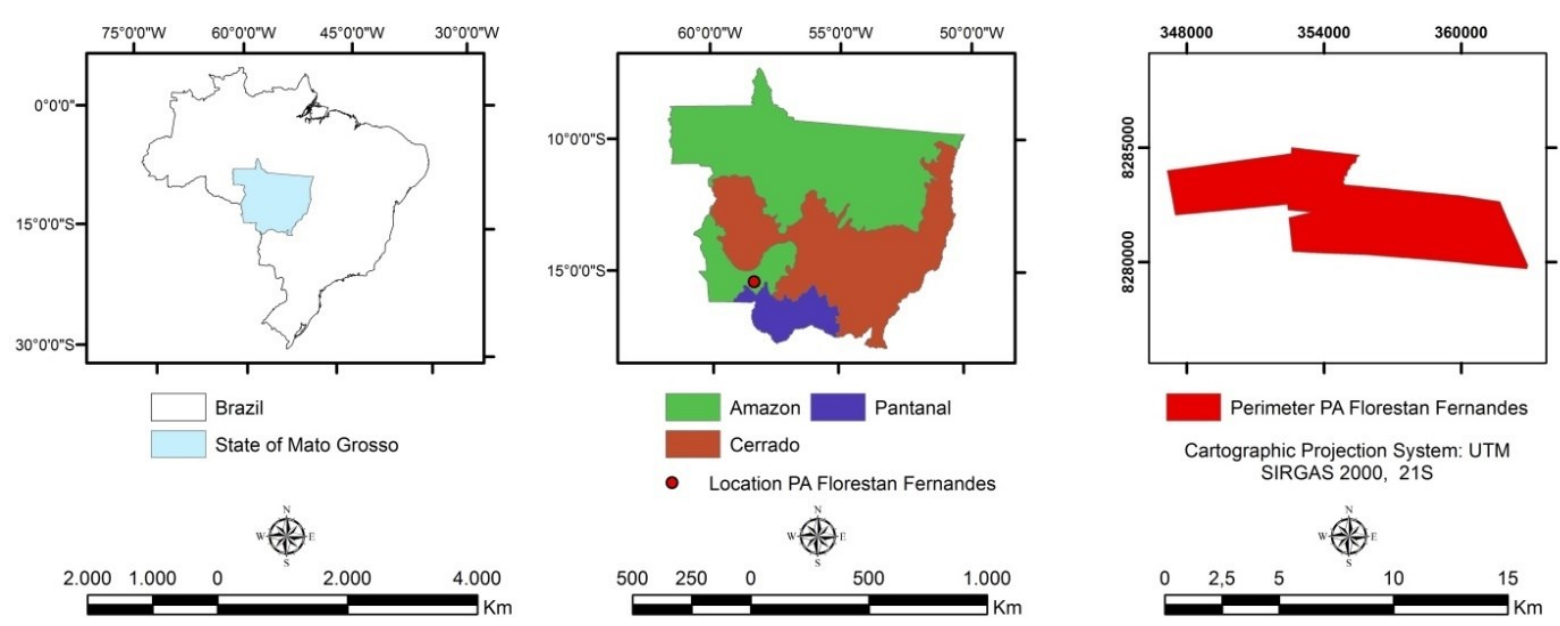

Figure 1. Location of the study area.

Table 1. Initial chemical and physical characteristics of the soil in the experimental area.

\begin{tabular}{|c|c|c|c|c|c|c|c|c|c|c|c|c|c|c|c|c|c|}
\hline Depth & $\begin{array}{c}\mathrm{pH} \\
\mathrm{H}_{2} \mathrm{O}\end{array}$ & $\mathrm{Ca}^{2+}$ & $\mathrm{Mg}^{2+}$ & $\mathrm{K}^{+}$ & $\mathrm{Al}^{3+}$ & $\mathrm{H}^{+} \quad \mathrm{T}$ & $\mathrm{OM}$ & $\mathrm{V} \quad \mathrm{m}$ & $\mathrm{P}$ & $\mathrm{S}$ & $\mathrm{Zn}$ & $\mathrm{Cu}$ & $\mathrm{Mn}$ & B & Sand & Silt & Clay \\
\hline $\mathrm{m}$ & & \multicolumn{5}{|c|}{$\mathrm{cmol}_{\mathrm{c}} \mathrm{dm}^{-3}$} & $\mathrm{~g} \mathrm{~kg}^{-1}$ & $\%$ & \multicolumn{6}{|c|}{$\mathrm{mg} \mathrm{dm^{-3 }}$} & \multicolumn{3}{|c|}{$\mathrm{g} \mathrm{kg}^{-1}$} \\
\hline $0-0.2$ & 6.1 & 2.0 & 0.6 & 0.2 & 0.1 & 3.56 .4 & 15.01 & 56.82 .1 & 37.9 & 7.3 & 17.5 & 2.5 & 130.30 & 0.43 & 796 & 107 & 96 \\
\hline $0.2-0.4$ & 6.5 & 2.6 & 0.8 & 0.1 & 0.2 & 2.15 .8 & 7.72 & 60.15 .4 & 26.2 & 9.3 & 5.2 & 2.2 & 114.60 & 0.25 & 809 & 106 & 85 \\
\hline
\end{tabular}

T: Total CEC at pH 7.0; OM: organic matter; V: base saturation; m: aluminum saturation.

Table 2. Analytical results of the reactive natural phosphate used in the experiment.

\begin{tabular}{lcc}
\hline \multicolumn{1}{c}{ Determinations } & Units & Results \\
\hline $\mathrm{pH} 0.01 \mathrm{M} \mathrm{CaCl}_{2}(1: 5)$ & & 7.3 \\
$\mathrm{C} / \mathrm{N}$ ratio (Total C. and Total N.) & $56 / 1$ \\
\hline Total Organic Matter (Combustion) & 5.44 \\
Total Carbon (Organic and Mineral) & 3.16 \\
Organic Carbon & 2.96 \\
Total Nitrogen & & 0.06 \\
Total Phosphorus $\left(\mathrm{P}_{2} \mathrm{O}_{5}\right)$ & 25.54 \\
Phosphorus - $\mathrm{P}_{2} \mathrm{O}_{5}(\mathrm{Citric}$ Acid 2\%) & 15.5 \\
Total Potassium $\left(\mathrm{K}_{2} \mathrm{O}\right)$ & & 0.3 \\
Total Calcium $(\mathrm{Ca})$ & & 37.2 \\
Total Magnesium (Mg) & & 0.38 \\
Total Sulfur $(\mathrm{S})$ & & 2.6 \\
\hline Total Zinc $(\mathrm{Zn})$ & & 110.4 \\
Total Copper $(\mathrm{Cu})$ & 14.4 \\
Total Manganese $(\mathrm{Mn})$ & $\mathrm{mg} \mathrm{kg}^{-1}$ & 48.2 \\
Total Boron $(\mathrm{B})$ & & 86.8 \\
Total Iron (Fe) & & 5640 \\
\hline CEC (Cation Exchange Capacity) & & 48 \\
\hline
\end{tabular}

The legume plants used were: velvet bean (Mucuna cinereum), Crotalaria juncea, Crotalaria ochroleuca and pigeon pea (Cajanus cajan). The grass used was millet (Pennisetum glaucum). In the plots in which spontaneous vegetation was maintained, there was a predominance of the following species: rough cocklebur, large cocklebur, common cockle burr (Xanthium strumarium); Benghal dayflower (Commelina benghalensis); Star burr (Acanthospermum hispidum); Guinea grass (Panicum maximum); Mogdad coffee (Senna occidentalis) and sida (Sida spp.).

The spacing between planting furrows was $0.5 \mathrm{~m}$ and density of 9 plants $\mathrm{m}^{-1}$ for velvet bean and

Rev. Caatinga, Mossoró, v. 35, n. 1, p. 14 - 25, jan. - mar., 2022 
20 plants $\mathrm{m}^{-1}$ for Crotalaria juncea, Crotalaria ochroleuca and pigeon pea. The populations obtained per hectare were approximately 180,000 plants $\mathrm{ha}^{-1}$ for velvet bean, 400,000 plants $\mathrm{ha}^{-1}$ for the species Crotalaria ochroleuca, Crotalaria juncea and pigeon pea, and 6,000,000 plants ha ${ }^{-1}$ for millet. The planting depth of the legume seeds ranged from 0.02 to $0.04 \mathrm{~m}$, with manual sowing. Millet was manually sown broadcast, in the amount of $50 \mathrm{~g}$ of seed plot $^{-1}$ and sowing depth of approximately 0.01 m (SPITALMIAK; WRIGHT; LANGDALE, 1995), using a rake for superficial incorporation.

The main cultural practices with legumes were: weeding between rows, manual cleaning in the rows and replanting at the sites with germination/ emergence failure. The cultural practices with millet, due to the broadcast sowing, were only manual cleaning and replanting. There was no occurrence of pests and diseases that harmed plants destined for green manure.

The plants were sampled within the usable area of the plots, at full flowering, by cutting their aerial part close to the ground, with their respective stems, leaves and flowers, with a $0.25 \mathrm{~m}^{2}$ frame. They were then placed in paper bags, identified, and dried in a forced air circulation oven at $65^{\circ} \mathrm{C}$, for 72 hours (dry mass), or until reaching constant weight. Finally, the samples were crushed and homogenized for the chemical analysis of the nutrients.

The cycle of plants used as green manure, from sowing to full flowering in year 1, varied according to the species, and the first to bloom, at 60 days after sowing (DAS), was millet (MI), followed by the pigeon pea (PP), at $83 \mathrm{DAS}$, then Crotalaria juncea $(\mathrm{CJ})$ at $92 \mathrm{DAS}$, Crotalaria ochroleuca $(\mathrm{CO})$ at 110 DAS and, finally, velvet bean (VB), which bloomed at $117 \mathrm{DAS}$. In year 2, the first species to bloom was PP at $88 \mathrm{DAS}$, followed by the species $\mathrm{CJ}$ and $\mathrm{MI}$, at $118 \mathrm{DAS}$, and finally, the two later species were $\mathrm{CO}$ and $\mathrm{VB}$, entering the reproductive stage at 129 DAS.

The plants used as green manure, not sampled, were also cut when more than $50 \%$ of their plots were at full flowering. After cutting, their respective masses were evenly distributed over the area of each plot, for decomposition/mineralization. In year 2, the experiment was repeated, with the difference that the seeds of legume plants were inoculated, according to MAPA (2011), with the following inoculants: TotalNitro Crotalaria spectabilis 02 DS LIQUIDO SEMIA, TotalNitro Guandu 6156, and TotalNitro Feijão Mucuna 02ds Semia 6158.

Soil sampling was randomly carried out in the usable area of the plots, collecting 3 single samples, to obtain one composite sample per plot after homogenization. Soil collections were carried out between the rows of the plants, in the 0-0.20 m layer.

Total organic carbon (C) and total nitrogen $(\mathrm{N})$ in plants and soil were determined by the combustion method in the LECO CHN 628 analyzer, TruSpec Micro model. P and $\mathrm{K}$ were extracted from plants by nitric-perchloric digestion (BATAGLIA et al., 1983) and determined according to the methodology of Donnagema et al. (2011). Once the nutrient contents in the plants and their respective dry masses were obtained (data available in LEITE, 2018), the quantities of the nutrients described were calculated according to Equation 1.

$$
Q_{N}=\left(\text { Content }_{N} \times \text { Yield }_{G M}\right)
$$

Where:

$Q_{N}=$ quantity of nutrients, in $\mathrm{kg} \mathrm{ha}^{-1}$; Content $_{N}=$ content of nutrients, in $\mathrm{g} \mathrm{kg}^{-1}$; Yield ${ }_{G M}=$ yield of green manures (dry mass), in $\mathrm{Mg} \mathrm{ha}^{-1}$.

$\mathrm{P}$ and $\mathrm{K}$ in soil were determined according to the methodology of Donnagema et al. (2011). From the results of the contents, the stocks in the were calculated according to Equation 2.

$$
\text { Stc }=\frac{(\text { Content } \times B D \times t)}{10}
$$

Where:

Stc $=$ stock of the element in the soil, in $\mathrm{kg} \mathrm{ha}^{-1}$; Content $=$ content of the element in the soil, $\mathrm{g} \mathrm{kg}^{-1}$; $B D=$ soil bulk density $\left(\mathrm{kg} \mathrm{dm}^{-3}\right)$, volumetric ring method (EMBRAPA, 1997);

$t=$ layer thickness $(20 \mathrm{~cm})$.

After cutting the plants used as green manure, second-season corn (BRS 4103 variety) was planted in all experimental plots, in succession, in March 2015 (year 1) and March 2016 (year 2). The spacing between corn planting furrows was $0.6 \mathrm{~m}$ with density of 4 plants per linear meter, planting depth of approximately $0.05 \mathrm{~m}$, forming a population of 66,000 plants per hectare (data not published). Reactive Natural Phosphate doses were used for the maintenance of the corn crop.

The data were subjected to tests of normality (Kolmogorov $\square$ Smirnov) and homogeneity of variance (Levene's criterion), both at 5\% probability level. Analysis of variance (ANOVA) and Tukey test $(p<0.05)$ were performed for comparations between the treatments of plants used as green manure and phosphorus doses, with further analysis of the levels whenever significant interaction $(\mathrm{p}<0.05)$ was detected

\section{RESULTS AND DISCUSSION}

Figure 2 shows the means of total $\mathrm{N}$ in plants and stock in soil. In year 1 , the quantities of $\mathrm{N}$ in the green manure plants ranged from 257 to $992 \mathrm{~kg} \mathrm{ha}^{-1}$, 
with significant differences (Tukey $-p<0.05$ ) between the means. There was greater $\mathrm{N}$ accumulation in the dry mass (DM) of Crotalaria juncea (CJ), followed by Crotalaria ochroleuca (CO) and lower accumulations in millet (MI), velvet bean (VB) and pigeon pea (PP). In year 2, the values of $\mathrm{N}$ in plants ranged from 225 to $744 \mathrm{~kg} \mathrm{ha}^{-1}$, also with significant differences (Tukey $-p<0.05$ ) between green manure plants. The highest values of $\mathrm{N}$ in the DM of the green manure plants were found in the species CJ, CO and PP. There was no significant interaction $(\mathrm{p}>0.05)$, in years 1 and 2 , between the green manure species and doses of phosphorous (P).

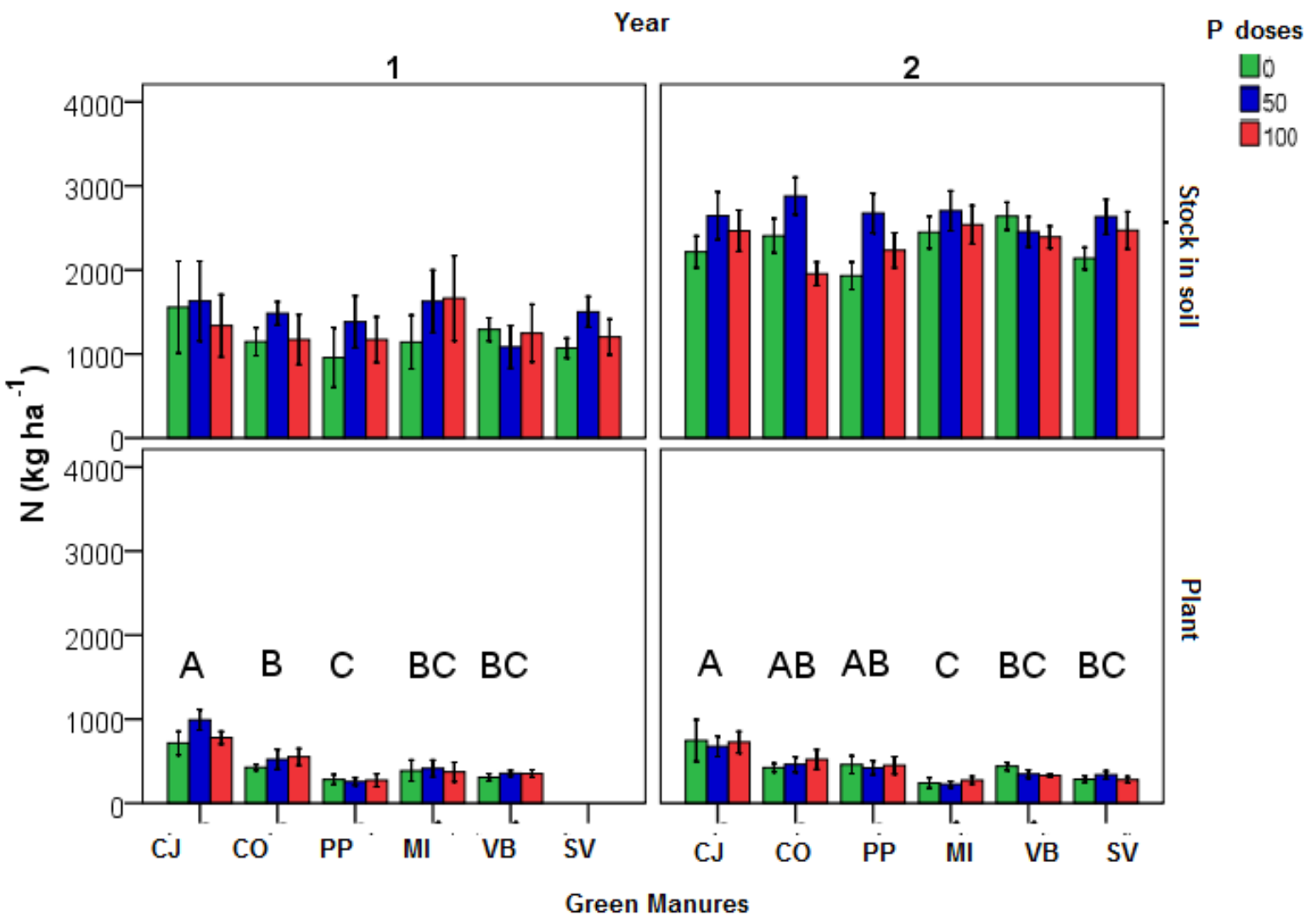

Error bars:+/- $1 \mathrm{SE}$

CJ: Crotalaria juncea; CO: Crotalaria ochroleuca; PP: pigeon pea; MI: millet, VB: velvet bean and SV: spontaneous vegetation. SE: standard error of the mean. Data transformed to Log (x) for statistical analyses. Different uppercase letters indicate significant difference between green manure plants (ANOVA and Tukey test $-\mathrm{p}<0.05$ ). Absence of letters indicates that there was no significant difference (ANOVA $-p>0.05$ ).

Figure 2. Total nitrogen $(\mathrm{N})$ in the plant and stock in soil subjected to management with green manure plants under three doses of phosphorus $(\mathrm{P})$.

$\mathrm{N}$ stock in soil ranged from 959 to $1664 \mathrm{~kg} \mathrm{ha}^{-1}$ in year 1 (Figure 2) and from 1931 to $2880 \mathrm{~kg} \mathrm{ha}^{-1}$ in year 2 , with no significant differences between the means ( $p>0.05)$. There was also no significant interaction between treatments with green manure plants and $P$ doses $(p>0.05)$ in the two years studied for this variable.

In year 2, the seeds of the legume plants were inoculated and, due to the BNF process, greater quantities of $\mathrm{N}$ were expected to be incorporated into the plants. However, this did not occur for all legumes; in most of them, $\mathrm{N}$ values in year 2 were lower than those in year $1 . \mathrm{N}$ supplies by legume plants can be very variable, depending on species, weather conditions (temperature and precipitation), photoperiod, latitude, and fertility, microbiology and type of soil, especially the presence of soil-native N-fixing bacteria (Rhizobium) (OLIVEIRA et al., 2015; MANGARAVITE et al., 2014; MASSAD et al., 2014; RECALDE et al., 2014).

The reduction of $\mathrm{N}$ in plants in year 2 may be related to increases of $\mathrm{N}$ in the soil, from year 1 to year 2 . BNF is a process regulated by the need of the environment and $\mathrm{N}$-fixing species. In the specific case of year 2, due to the increase in the availability of $\mathrm{N}$ in the soil, this may have interfered in the BNF process, with the consequent reduction of $\mathrm{N}$ in the dry mass of the legume plants. 
The competition between the strains inoculated in the seeds and native fixing bacteria existing in the soil may also interfere with the BNF process. Rufini et al. (2014) found high nodulation in plants that did not receive inoculants and attributed their results to the presence of native $\mathrm{N}$-fixing bacteria in the soil. Cavalcante et al. (2017), studying the application of inoculants in the legume species cowpea, observed no significant effect of the presence and absence of inoculation in the seeds on yield. These authors detected the presence of native $\mathrm{N}$-fixing bacteria and concluded that the addition of new bacteria by inoculation can cause competition between them and, consequently, hamper the development of the crop.
Figure 3 shows the results of carbon $(C)$ in green manure plants and stock in soil. In year 1 , the $\mathrm{C}$ added by the DM of their aerial part ranged from 3519 to $13208 \mathrm{~kg} \mathrm{ha}^{-1}$. The plants that most assimilated $\mathrm{C}$ were: $\mathrm{CJ}$, MI and $\mathrm{CO}$ (Tukey $-p<0.05$ ). In year 2 , the inputs of $C$ by the plants ranged from 4677 to $13189 \mathrm{~kg} \mathrm{ha}^{-1}$, and the greatest quantity was observed in the species CJ (Tukey $-p<0.05$ ). In the two years studied, there was no significant interaction between $\mathrm{P}$ doses and $\mathrm{C}$ means in green manure plants. The $\mathrm{C}$ stock in soil varied both in year 1 and in year 2, from 21244 to $30883 \mathrm{~kg} \mathrm{ha}^{-1}$, without differences and without significant interactions $(\mathrm{p}>0.05)$ between treatments with green manures and $\mathrm{P}$ doses.

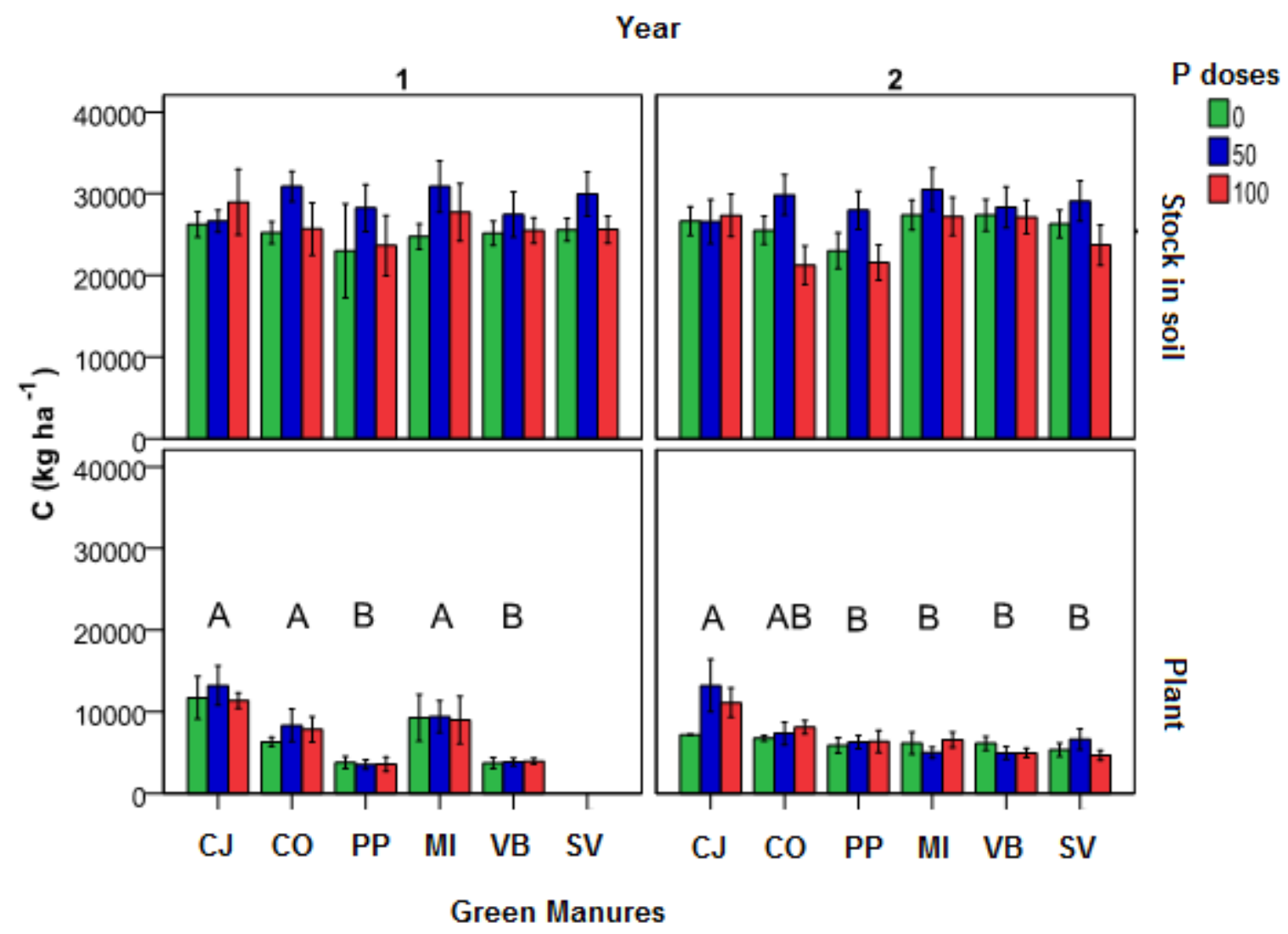

Error bars:+/- $1 \mathrm{SE}$

CJ: Crotalaria juncea; CO: Crotalaria ochroleuca; PP: pigeon pea; MI: millet, VB: velvet bean and SV: spontaneous vegetation. SE: standard error of the mean. Data transformed to $\log (\mathrm{x})$ for statistical analyses. Different uppercase letters indicate significant difference between green manure plants (ANOVA and Tukey test $-\mathrm{p}<0.05$ ). Absence of letters indicates that there was no significant difference (ANOVA $-p>0.05$ ).

Figure 3. Total carbon $(\mathrm{C})$ in the plant and stock in soil subjected to management with green manure plants under three doses of phosphorus $(\mathrm{P})$.

According to Taiz and Zeiger (2004), the different architectures of plants interfere with the interception of light; once they are supplied with water and nutrients, it will result in different assimilated quantities of $\mathrm{C}$. In addition, the anatomy of the leaves interferes with the photosynthetic responses, in the way $\mathrm{CO}_{2}$ diffuses from the atmosphere to the leaves, all depending on the species and, in the case of this study, on the different plants used as green manure.

The obtained results of $\mathrm{C}$ in the plants are above those found in other studies (PEREIRA; 
SOARES; MIRANDA, 2016; LIMA et al., 2010; CALVO et al., 2010). The higher value of $C$ found in the species CJ, both in year 1 and in year 2, is related to its rapid initial growth in the first 40 days after sowing - DAS (TEODORO et al., 2011)

Rosa et al. (2017) obtained results similar to those of the present study, with low sensitivity of total soil organic $\mathrm{C}$ between treatments with management systems. According to these authors, it should be considered that the increase in total $\mathrm{C}$ content in the soil occurs gradually and its benefits are visualized over the years.
Figure 4 shows the quantities of $\mathrm{P}$ in the plants, which ranged in year 1 from 13 to $68 \mathrm{~kg} \mathrm{ha}^{-1}$. The highest quantities of $\mathrm{P}$ were accumulated in the green manure species $\mathrm{CJ}, \mathrm{CO}$ and $\mathrm{MI}$ and the lowest quantities in PP and VB $(p<0.05)$. In year 2 , the quantities of $\mathrm{P}$ in the plants ranged from 33 to $182 \mathrm{~kg} \mathrm{ha}{ }^{-1}$, with the highest amount of $\mathrm{P}$ accumulated in $\mathrm{CJ}$ and the lowest quantities in the others $(p<0.05)$. There was no significant interaction between the doses of Reactive Natural Phosphate (RNP) and the $\mathrm{P}$ accumulated in the green manure plants in the two years studied.

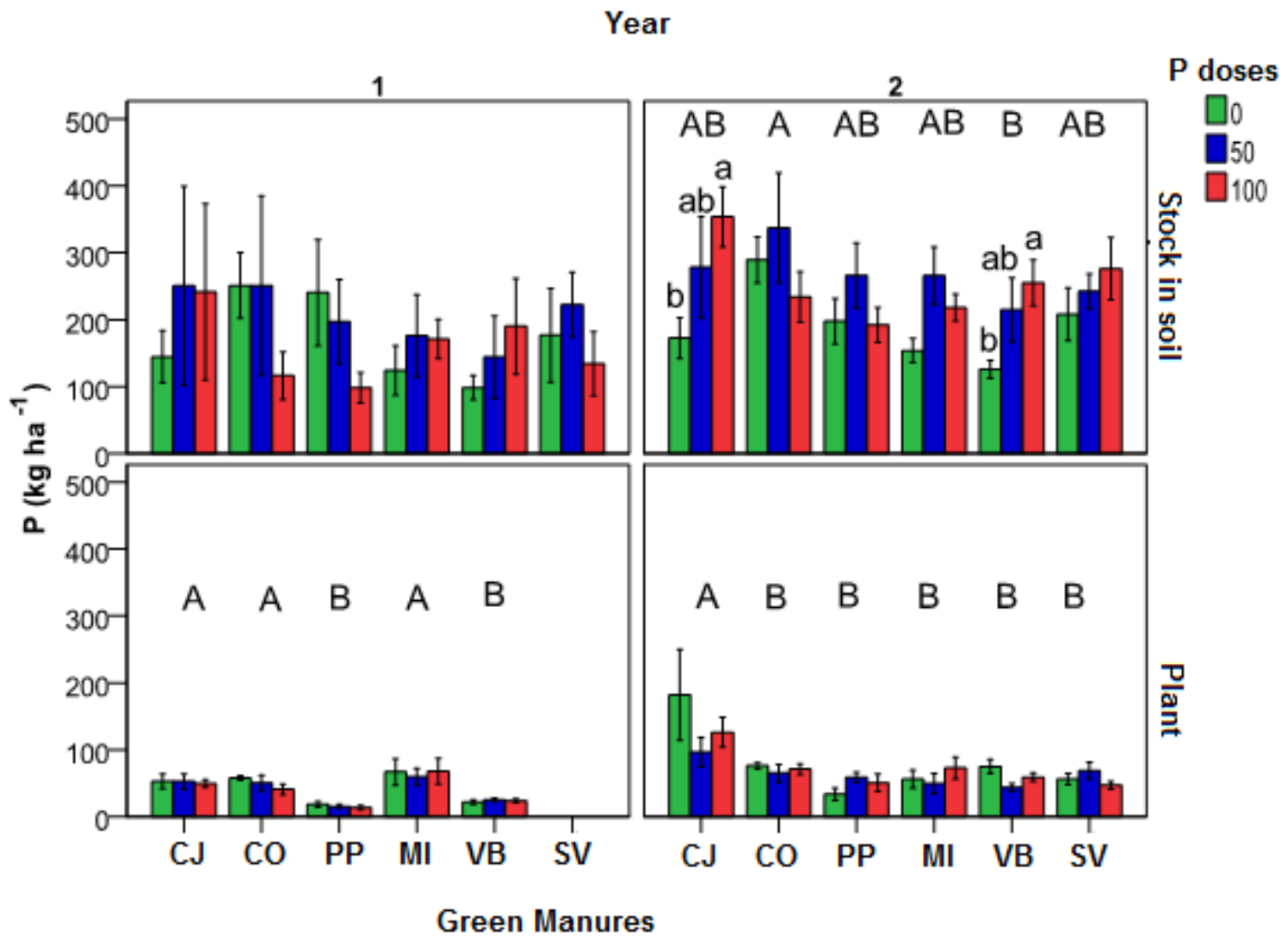

Error bars:+/- $1 \mathrm{SE}$

CJ: Crotalaria juncea; CO: Crotalaria ochroleuca; PP: pigeon pea; MI: millet, VB: velvet bean and SV: spontaneous vegetation. SE: standard error of the mean. Data were transformed to Log (x) for statistical analysis. Different uppercase letters indicate significant difference between green manure species; different lowercase letters indicate significant difference between $\mathrm{P}$ doses for each green manure plant (ANOVA and Tukey test $-\mathrm{p}<0.05$ ). Absence of letters indicates that there was no significant difference (ANOVA $-p>0.05$ ).

Figure 4. Phosphorus $(\mathrm{P})$ in the plant and stock in soil subjected to management with green manure plants under three doses of phosphorus $(\mathrm{P})$.

The obtained results of $\mathrm{P}$ in the plants in the present study were higher than those found in other studies (XAVIER; OLIVEIRA; SILVA, 2017; SILVA et al., 2017), which are justified by the high production of dry mass and satisfactory weather conditions for the development of plants used as green manure (LEITE, 2018) and by the high $\mathrm{P}$ content in the soil (P: $37.9 \mathrm{mg} \mathrm{dm}^{-3}$, Clay: $9.6 \%$ ) at the beginning of the experiment.

The $\mathrm{P}$ stock in soil, in year 1 (Figure 4), ranged from 98 to $251 \mathrm{~kg} \mathrm{ha}^{-1}$, with no significant differences between green manures and no significant interaction with RNP doses $(p>0.05)$. In year 2 , the $P$ stock in soil ranged from 126 to $354 \mathrm{~kg}$ $\mathrm{ha}^{-1}$ with significant differences according to the following descending order: $\mathrm{CO}(\mathrm{A}), \mathrm{CJ}(\mathrm{AB}), \mathrm{PP}$ 
(AB), MI (AB), SV (AB), VB (B). There was significant interaction between the RNP doses and the green manure species $\mathrm{CJ}$ and $\mathrm{VB}$, according to the following descending order: $100(\mathrm{a}) ; 50(\mathrm{ab})$ and $0 \mathrm{~kg}$ ha-1 of P2O5 (b). Means of P stock in soil with equal letters did not differ significantly by Tukey test $(\mathrm{p}>0.05)$.

The significant differences observed in the $\mathrm{P}$ stock in soil (year 2) are in accordance with the results obtained by Hall et al. (2010), according to whom plants access $\mathrm{P}$ in the soil in different ways and degrees of adaptation, some utilize inorganic phosphorus $(\mathrm{Pi})$, through their roots or associations with mycorrhiza, and some utilize organic phosphorus (Po), through specialized enzymatic mechanisms (acid and alkaline phosphatases). Casali et al. (2016) reported that plant species have different $\mathrm{P}$ absorption and accumulation capacity, but the main determinant is the availability of $\mathrm{P}$ in the soil.

The quantities of potassium $(\mathrm{K})$ accumulated in plants used as green manure in year 1 (Figure 5) ranged from 70 to $329 \mathrm{~kg} \mathrm{ha}^{-1}$. There was a significant difference $(p<0.05)$ between the green manure plants, with the highest values obtained in the species $\mathrm{CJ}, \mathrm{CO}$ and MI, and lowest values in the species PP and VB. In the second year, the quantities of $\mathrm{K}$ in the plants varied from 189 to $892 \mathrm{~kg} \mathrm{ha}^{-1}$, with significant differences $(p<0.05)$ between the green manure species, being higher in $\mathrm{CJ}$, intermediate in $\mathrm{CO}$ and lower in the species PP, MI, $\mathrm{VB}$ and in the treatment with SV. There was no significant interaction (years 1 and 2) between $\mathrm{P}$ doses and green manure plants.

The $\mathrm{K}$ stock in soil in year 1 (Figure 5) ranged from 110 to $329 \mathrm{~kg} \mathrm{ha}^{-1}$, with significant differences $(p<0.05)$ between treatments with green manure plants, according to the following descending order: $\mathrm{MI}(\mathrm{A}), \mathrm{SV}(\mathrm{AB}), \mathrm{CJ}(\mathrm{ABC}), \mathrm{CO}$ $(\mathrm{ABC}), \mathrm{PP}(\mathrm{BC})$ and $\mathrm{VB}(\mathrm{C})$. Means of $\mathrm{K}$ stocks in the soil with equal letters did not differ significantly by Tukey test $(p>0.05)$. There was no significant interaction in the $\mathrm{K}$ stock in the soil between $\mathrm{P}$ doses and green manure plants, in the two years studied.

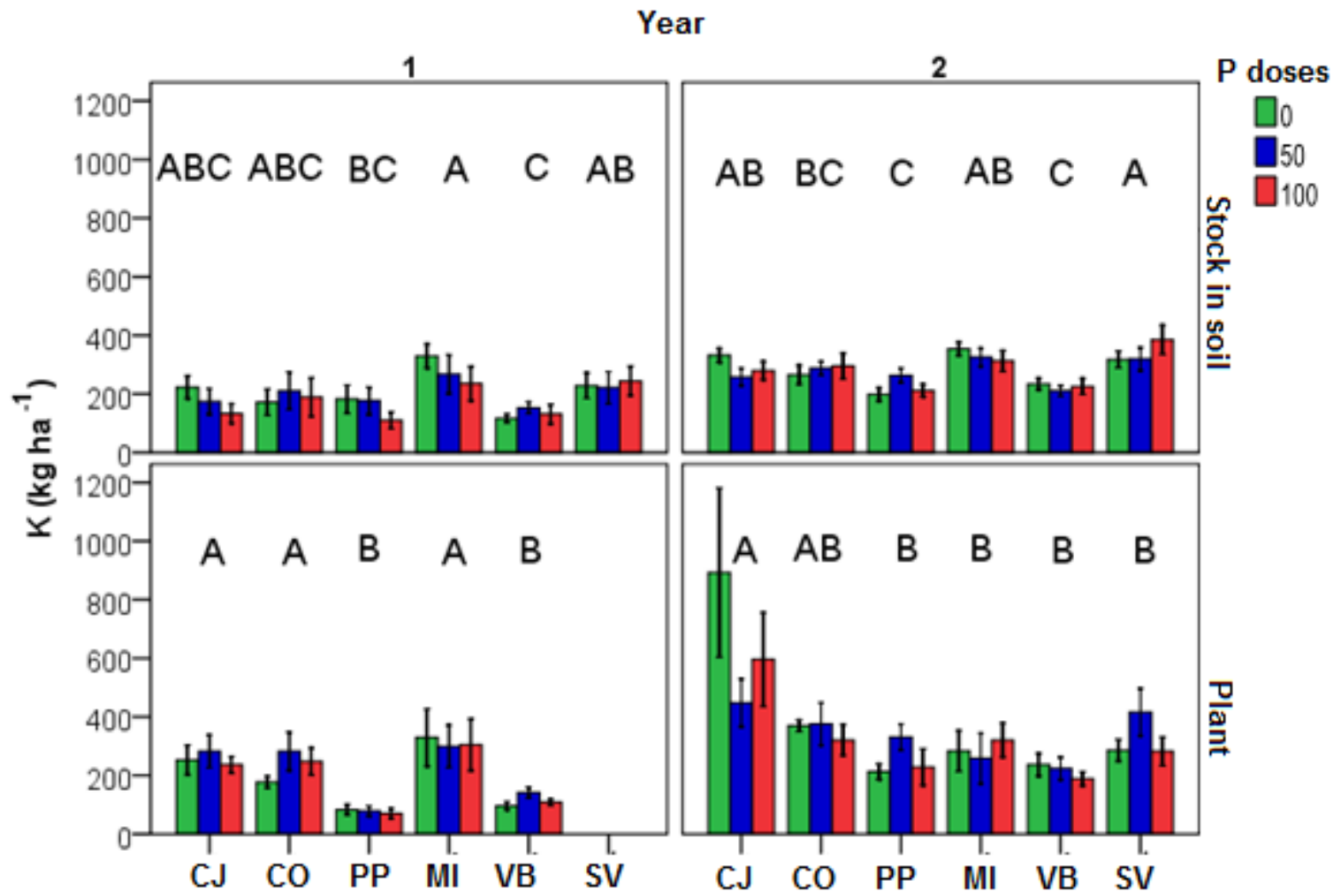

Green Manures

\section{Error bars:+l- $1 \mathrm{SE}$}

CJ: Crotalaria juncea; CO: Crotalaria ochroleuca; PP: pigeon pea; MI: millet, VB: velvet bean and SV: spontaneous vegetation. SE: standard error of the mean. Data were transformed to Log (x) for statistical analysis. Different uppercase letters indicate significant difference between green manure species; different lowercase letters indicate significant difference between $\mathrm{P}$ doses for each green manure plant (ANOVA and Tukey test $-\mathrm{p}<0.05$ ). Absence of letters indicates that there was no significant difference (ANOVA $-\mathrm{p}>0.05$ ).

Figure 5. Potassium $(\mathrm{K})$ in the plant and stock in soil subjected to management with green manure plants under three doses of phosphorus (P). 
Favarato et al. (2015) did not find significant differences between grasses and legumes used as green manure, regarding the $\mathrm{K}$ contents in the soil. Espíndola et al. (2006), when studying the decomposition and release of $\mathrm{K}$ in different cover crops, observed higher $\mathrm{K}$ accumulation in the soil under grasses. The results of this study corroborate those found by the authors mentioned above; the highest values of $\mathrm{K}$ in the soil were found under MI (year 1) (grass), but the legume plants also stood out in terms of K supply, being statistically equal to the $\mathrm{K}$ stocks in the soil under MI. Another important highlight was the treatment under SV, which in year 2 had the highest $\mathrm{K}$ stock in the soil, which can be explained, according to Lorenzi (2008), by the high capacity of these plants to absorb and accumulate nutrients.

Figure 6 shows the carbon/nitrogen $(\mathrm{C} / \mathrm{N})$ ratios in plants and soil. In plants (year 1), the $\mathrm{C} / \mathrm{N}$ ratios varied between 11 and 23 , with the highest value observed in MI and the lowest value in VB $(\mathrm{p}<0.05)$. The species CJ, CO and PP showed intermediate ratios and no significant differences between them $(\mathrm{p}>0.05)$. In year 2 , the $\mathrm{C} / \mathrm{N}$ ratios in plants ranged from 14 to $26(\mathrm{p}<0.05)$, being higher in the species $\mathrm{MI}$ and $\mathrm{CJ}$, intermediate in $\mathrm{SV}$ and $\mathrm{CO}$, and lower in the species PP and VB.

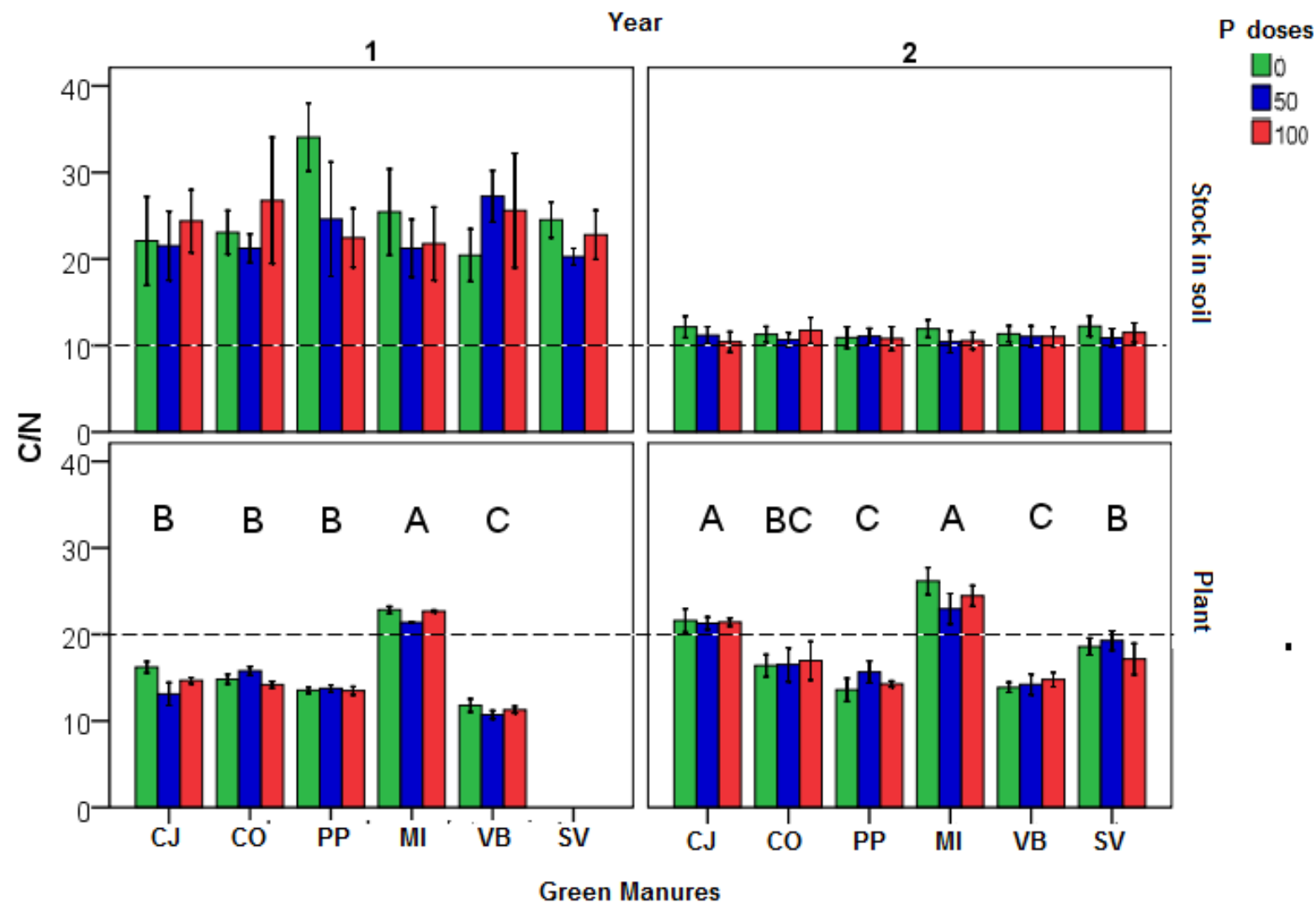

Error bars:+/- $1 \mathrm{SE}$

CJ: Crotalaria juncea; CO: Crotalaria ochroleuca; PP: pigeon pea; MI: millet, VB: velvet bean and SV: spontaneous vegetation. SE: standard error of the mean. Data were transformed to Square Root $(x+1)$ for statistical analysis. Dashed lines represent the limits between mineralization/immobilization of plants and soil. Different uppercase letters indicate significant difference between green manure species. Absence of letters indicates that there was no significant difference (ANOVA - p >0.05).

Figure 6. Carbon/nitrogen ratios $(\mathrm{C} / \mathrm{N})$ in the plant and soil subjected to management with green manure plants under three doses of phosphorus $(\mathrm{P})$.

The lowest $\mathrm{C} / \mathrm{N}$ ratios obtained in legume plants (except for $\mathrm{CJ}$, in year 2) are of great interest for the managements that will be recommended, especially those of legume plants, which in addition to the low $\mathrm{C} / \mathrm{N}$ ratio, contain soluble substances in large quantities, such as free amino acids and reducing sugars, which facilitates the action of microorganisms in the decomposition process, providing nutrients for subsequent crops for food production in family farming (CORREA et al., 2014).

The $\mathrm{C} / \mathrm{N}$ ratios in the soil in year 1 (Figure 6) ranged from 20 to 34 , with no significant differences $(p>0.05)$ between treatments with green manure 
plants. In year 2 , the $\mathrm{C} / \mathrm{N}$ ratios in the soil ranged from 10 to 13 , also without significant differences $(p>0.05)$ between the treatments with green manures. In the two years studied, there was no significant interaction between treatments with fertilization plants and $\mathrm{P}$ doses.

When comparing the $\mathrm{C} / \mathrm{N}$ ratios in the soil between the years studied, lower values were observed in the second year. According to Fornasieri Filho (2007), the decomposition of organic matter is mainly regulated by the $\mathrm{C} / \mathrm{N}$ ratio present in the soil. Buckman and Brady (1967) reported that the appropriate $\mathrm{C} / \mathrm{N}$ ratio in the soil should be between 10 and 12 . The results of this study indicate that the green manure plants at the end of the experiment added $\mathrm{C}$ and $\mathrm{N}$ to the soil in a balanced way, which will be used by microorganisms, improving soil quality and increasing the contents of nutrients for food production in family farming.

\section{CONCLUSIONS}

Legume green manure plants accumulated high quantities of nutrients in their dry masses, which after mineralization increased the stocks of nitrogen $(\mathrm{N})$, phosphorus $(\mathrm{P})$ and potassium $(\mathrm{K})$ in the soil. The species Crotalaria juncea (CJ) accumulated the highest amount of $\mathrm{N}$.

The legume species Crotalaria ochroleuca can be recommended for family farming, being a technically feasible alternative of soil management for this producing class.

This work concluded that it is possible to increase soil fertility, and the proposed managements supply carbon to the agroecosystem, which activates soil microbiology, promoting ecosystem services that will ensure the sustainability of family farming.

\section{ACKNOWLEDGMENTS}

To the Mato Grosso State University, Cáceres Campus, for providing the Soil and Plant Nutrition Laboratory. To Sonia Tolomeu Rosa, Edson and Rosalino, settled in PA Florestan Fernandes, who made their homes and land available for this work to be carried out. Finally, I thank INCRA for granting me the leave to conduct this study.

\section{REFERENCES}

ANDA - Associação Nacional para Difusão de Adubos. Principais indicadores do setor de fertilizantes. Available at: <http://www.anda.org.br/ estatistica/Principais Indicadores 2014.pdf $>$. Access on: Jun. 10, 2014.
ANDA - Associação Nacional para Difusão de Adubos. Setor de Fertilizantes-Anuário Estatístico de 2018, 1 st ed.; Associação Nacional para Difusão de Adubos (ANDA): São Paulo, Brazil, 2019.

BAtaglia, O. C. et al. Método de Análise Química de Plantas. Campinas, SP: Instituto Agronômico - IAC, 1983. 48 p. (Boletim Técnico, 78).

BUCKMAN, H. O.; BRADY, N. C. Natureza e propriedade dos solos. Rio de Janeiro, RJ: USAID, $1967.594 \mathrm{p}$

CALVO, L. et al. Produtividade de massa e relação $\mathrm{c} / \mathrm{n}$ de monocultivos e consórcios de guandu-anão, milheto e sorgo em três épocas de corte. Bragantia, 69: 77-86, 2010.

CASALI, C. A. et al. Benefícios do uso de plantas de cobertura de solo na ciclagem de fósforo. In: TIECHER, T. (Ed.). Manejo e conservação do solo e da água em pequenas propriedades rurais no sul do Brasil: práticas alternativas de manejo visando a conservação do solo e da água. Porto Alegre, RS: UFRGS, 2016, Capítulo II, p. 23-33.

CAVALCANTE, A. P. et al. Inoculação das cultivares locais de feijão-caupi com estirpes de rizóbio. Revista de Ciências Agrárias, 60: 38-44, 2017.

CORRÊA, A. L. et al. Adubação verde com crotalária consorciada ao minimilho antecedendo a couve-folha sob manejo orgânico. Revista Ceres, 61: 956-963, 2014

DONNAGEMA, G. K. et al. Manual de métodos de análise de solos. 2. ed. rev. Rio de Janeiro, RJ: Embrapa Solos, 2011. 230 p. (Embrapa Solos. Documentos, 132).

EMBRAPA - Empresa Brasileira de Pesquisa Agropecuária. Sistema brasileiro de classificação de solos. 5. ed., ver. e ampl. Brasília, DF: Embrapa, 2018. $356 \mathrm{p}$

EMBRAPA - Empresa Brasileira de Pesquisa Agropecuária. Manual de métodos de análises de solo. 2. ed. de Janeiro, RJ: EMBRAPA, 1997. 212 p.

ESPÍNDOLA, J. A. A. et al. Decomposição e liberação de nutrientes acumulados em leguminosas herbáceas perenes consorciadas com bananeira. Revista Brasileira de Ciência do Solo, 30: 321-328, 2006.

FAVARATO, L. F. e al. Atributos químicos do solo com diferentes plantas de cobertura em sistema de plantio direto orgânico. Revista Brasileira de 
Agropecuária Sustentável, 5: 19-28, 2015.

FINNEY, D. M.; WHITE, C. M.; KAYE, J. P. Biomass production and carbon/nitrogen ratio influence ecosystem services from cover crop mixtures. Agronomy Journal, 108: 39-52, 2016.

FORNASIERI, FILHO, D. Manual da Cultura do Milho. Jaboticabal, SP: Funep, 2007. 576 p.

HALL, H. et al. Cover crops alter phosphorus soil fractions and organic matter accumulation in a Peruvian caca o agroforestry system. Agroforestry Systems, 80: 447-455, 2010.

HERNANI, L. C.; PADOVAN, M. P. Adubação verde na recuperação de solos degradados. In: LIMA FILHO, O. F. et al. (Eds.). Adubação verde e plantas de cobertura no Brasil: fundamentos e práticas. Brasília,

DF: Embrapa, 2014. p. 371-398.

IBGE - Instituto Brasileiro de Geografia e Estatística. Censo Agropecuário 2017 - Resultados Preliminares. IBGE, Rio de Janeiro-RJ 2017. Available at: <https://sidra.ibge.gov.br/pesquisa/ censo-agropecuario/censo-agropecuario-2017>. Access on: Apr. 21, 2019.

LEITE, M. H. S. Interações entre adubos verdes e fosfato natural na ciclagem de nutrientes do solo para produção de milho na agricultura familiar. 2018. 132 f. Tese (Doutorado em Agricultura Tropical: área de concentração Recursos Naturais) Universidade Federal de Mato Grosso, Cuiabá, 2018.

LIMA, J. D. et al. Arranjo espacial, densidade e época de semeadura no acúmulo de matéria seca e nutrientes de três adubos verdes. Pesquisa Agropecuária Tropical, 40: 531-540, 2010.

LORENZI, H. Plantas daninhas do Brasil: terrestres, aquáticas, parasitas e tóxicas. 4. ed. Nova Odessa, SP: PLANTARUM, 2008. 640 p.

MALUF, H. J. G. M. et al. Crop residue decomposition and nutrient mineralization in soil with fifferent textures. Revista Brasileira de Ciência do Solo, 39: 1681-1689, 2015.

MANGARAVITE, J. C, S. et al. Phytomass production and nutrient accumulation by green manure species. Revista Ceres, 61:732-739, 2014.

MAPA - Ministério da Agricultura, Pecuária e Abastecimento. Instrução Normativa SDA $\mathbf{N}^{\mathbf{0}}$ 13, de 24 de março de 2011.

MASSAD, M. D. et al. Desempenho de milho verde em sucessão a adubação verde com crotalária, submetido a doses crescentes de esterco bovino, na caatinga mineira. Magistra, 26: 322-332, 2014.

OLIVEIRA, P. P. A. et al. Emissões de GEEs e amônia em sistemas pastoris: mitigação e boas práticas de manejo. In: SIMPÓSIO SOBRE MANEJO DA PASTAGEM, 27., 2015, Piracicaba. Anais... Piracicaba: FEALQ, 2015. p. 179-223.

OLIVEIRA, P. M.; MALAGOLLI, G. A.; CELLA, D. Mercado de fertilizantes: dependência de importações do Brasil. Revista Interface Tecnológica, 16: 489-498, 2019.

PEREIRA, N. S.; SOARES, I.; MIRANDA, F. R. Biomassa e acúmulo de nutrientes por espécies de leguminosas utilizadas como adubo verde na região do Jaguaribe-Apodi, Ceará, Brasil. Revista Verde de Agroecologia e Desenvolvimento Sustentável, 11: 11-14, 2016.

RECALDE, K. M. G. et al. Mandioca em Sucessão a Plantas de Cobertura sob Bases Agroecológicas no Mato Grosso do Sul. Cadernos de Agroecologia, 9: $1-12,2014$.

ROSA, D. M. et al. Substâncias húmicas do solo cultivado com plantas de cobertura em rotação com milho e soja. Revista Ciência Agronômica, 48: 221 $-230,2017$.

RUFINI, M. et al. Symbiotic efficiency and identification of rhizobia that nodulate cowpea in a Rhodic Eutrudox. Biology and Fertility of Soils, 50: $115-122,2014$

SANTOS, M. V. Zoneamento Sócio-EconômicoEcológico: diagnóstico sócio-econômico-ecológico do Estado de Mato Grosso e assistência técnica na formulação da $\mathbf{2}^{\mathbf{a}}$ aproximação. Cuiabá, MT: SEPLAN-MT, 2000. 352 p.

SILVA, M. S. et al. Acúmulo de nutrientes e massa seca produzida por Crotalaria juncea cultivada no cerrado. Brazilian Journal of Biosystems Engineering, 11: 26-36, 2017.

SILVA, J. et al. Sistemas de manejo em transição agroecológica: coerências e contradições na prática cotidiana de agricultores familiares. Revista Brasileira de Agroecologia, 9: 98-113, 2014.

SPITALMIAK, D. L.; WRIGHT, D. L.; LANGDALE, G. Grain peal millet agronomic performance in relation to conventional and striptillage. In: National Grain Pearl Millet, 1., Tifton. Proceedings. [S.1]: University of Georgia, 1995. p. 24-27.

TAIZ, L.; ZEIGER, E. Fisiologia vegetal. Porto 
Alegre, RS: Artmed, 2004. 719 p.

TAVARES, M. F. F.; HABERLI JUNIOR, C. O mercado de fertilizantes no Brasil e as influências mundiais. São Paulo, SP: Escola Superior de Propaganda e Marketing; 2011. 16 p.

TEODORO, R. B. et al. Aspectos Agronômicos de Leguminosas para Adubação Verde no Cerrado do Alto Vale do Jequitinhonha. Revista Brasileira de Ciência do Solo, 35: 635-643, 2011.

XAVIER, F. A. S.; OLIVEIRA, J. I. A.; SILVA, M. $\mathrm{R}$. Decomposition and nutrient release dynamics of shoot phytomass of cover crops in the Recôncavo Baiano. Revista Brasileira de Ciência do Solo, 41, e0160103, 2017. 